\title{
Pengenalan Konsep Perkalian Menggunakan Media Rak Telur Rainbow pada Anak Usia Dini
}

\author{
Ihsan Maulana ${ }^{{ }}{ }_{1}$, Yaswinda ${ }^{2}$, Nurhamidah Nasution ${ }^{3}$ \\ Pendidikan Anak Usia Dini, Universitas Negeri Padang \\ DOI: $\underline{10.31004 / o b s e s i . v 4 i 2.370}$
}

\begin{abstract}
Abstrak
Matematika selama ini dianggap materi pembelajaran paling menyeramkan, sehingga banyak anak-anak kurang tertarik untuk mempelajarinya, salah satunya yaitu materi tentang perkalian.Oleh sebab itu pada pembelajaran di SD kelas rendah guru harus memberikan kondisi pembelajaran yang nyata.Penelitian ini bertujuan untuk mengetahui kemampuan anak dalam pengenalan konsep bilangan pada anak usia 6-7 tahun di SD. Penelitian ini merupakan penelitian kualitatif dan diuraikan dalam bentuk diskriptif. Berdasarkan Hasil penelitan menunjukkan bahwa pengenalan konsep perkalian menggunakan rak telur rainbow membuat siswa tidak takut lagi belajar matematika dan pembelajaran matematika jadi menyenangkan dan perkembangan kognitif siswa menjadi berkembang karena media rak telur rainbow ini memberikan bentuk konkrit dari konsep perkalian, yang salah satu konsepnya yaitu penjumlahan yang berulang.
\end{abstract}

Kata Kunci: konsep perkalian; rak telur; rainbow.

\begin{abstract}
Mathematics has been considered the most scary learning material, so many children are less interested in learning it, one of which is the material about multiplication. Therefore, in learning in elementary low-grade teachers must provide real learning conditions. This study aims to determine the ability of children in the introduction of the concept of numbers in children aged 6-7 years in elementary school. This research is a qualitative research and described in a descriptive form. Based on the results of research show that the introduction of the concept of multiplication using rainbow egg shelves makes students no longer afraid of learning mathematics and mathematics learning becomes fun and the cognitive development of students becomes developed because the rainbow egg rack media gives a concrete form of the multiplication concept, one of the concepts is the total addition over and over
\end{abstract}

Keywords: multiplicationconcep; egg rack; rainbow.

Copyright (c) 2020 Ihsan Maulana, Yaswinda, Nurhamidah Nasution

$\triangle$ Corresponding author :

Email Address : ihsanmaulana843@gmail.com (Padang, Indonesia)

Received 12 December 2019, Accepted 26 December 2019, Published 7 January 2020 


\section{PENDAHULUAN}

National Association for the Education of Young Children (NAEYC) yaitu asosiasi para pendidik anak yang berpusat di Amerika mendefinisikan rentang usia anak usia dini berdasarkan perkembangan hasil penelitian di bidang psikologi perkembangan anak yang mengindikasikan bahwa terdapat pola umum yang dapat diprediksi menyangkut perkembangan yang terjadi selama 8 tahun pertama kehidupan anak(Suryana, Elina, Nurevi, \& Ratnawilis, 2015). NAEYC membagi anak usia dini menjadi 0-3 tahun, 3-5 tahun, dan 6-8 tahun(Astuti \& Aziz, 2019)Menurut (Yaswinda, Yulsyofriend, \& Mayar, 2018)anak usia dini merupakan kelompok manusia yang berada pada proses pertumbuhan dan perkembangan. Masa anak usia dini merupakan masa keemasan atau sering disebut Golden Age. Pada masa ini otak anak mengalami perkembangan paling cepat sepanjang sejarah kehidupannya(Fauziddin \& Mufarizuddin, 2018). Hal ini mengisyaratkan bahwa anak usia dini adalah individu yang unik yang memiliki pola pertumbuhan dan perkembangan fisik, kognitif, sosio-emosional, kreativitas, bahasa dan komunikasi yang khusus sesuai dengan tahapan yang sedang dilalui oleh anak tersebut.

Sebagai peletak dasar pendidikan anak, pendidik anak usia dini memberikan pembelajaran sesuai dengan sifat unik anak. Pembelajaran yang diberikan saling berkoordinasi dengan tahapan perkembangan anak.Salah satu tahap perkembangan kognitif anak yang dapat di kembangkan yaitu dengan mengajarkan Matematika.Menurut (Suyanto, 2005)Matematika di PAUD itu merupakan kegiatan belajar tentang konsep matematika melalui aktifitas bermain dalam kehidupan sehari-hari dan bersifat ilmiah.

Menurut (Suyanto, 2005)) secara umum konsep matematika untuk anak usia dini adalah: (1) memilih, membandingkan, dan mengurutkan, (2) klasifikasi, (3) menghitung, (4) angka, (5) pengukuran, (6) geometri, (7) membuat grafik, (8) pola, dan (9) problem solving yaitu perkalian dan pembagian. Konsep- konsep tersebut perlu untuk diajarkan dan diperkenalkan kepada anak sebagai bekal kehidupannya kelak.(Abin, 2017)Untuk itu dalam pembelajaran matematika terdapat dua aspek yang perlu diperhatikan, yaitu: (1) matematika sebagai alat untuk menyelesaikan masalah, dan (2) matematika merupakan sekumpulan keterampilan yang harus dipelajari

Menurut Ani, Maulana, \& Sunaengsih, (2018) "mathematics must be connected to reality and mathematics as human activity".Pertama matematika harus dekat dengan siswa dan harus relevan dengan kehidupan sehari-hari. Kedua adalah matematika sebagai aktivitas manusia" .Menurut (Ridlo \& Riwanto, 2018)) ada lima karakteriktik dalam pembelajaran matematika, (1) Dalam mengajarkan mata pelajaran matematika, guru harus menghubungkan materi dengan kehidupan sehari-hari. (2) Dengan menggunakan alat atau media saat pembelajaran dapat menemukan konsep matematika. (3) Hasil yang di dapat siswa dalam pembelajaran dapat diterapkan dalam masalah lain. (4) Proses pembelajaran dan pendekatan dilaksanakan secara bersamaan. (5) Dalam pembelajaran matematika guru harus menghubungkan materi dengan pokokan bahasan yang lain secara utuh.

Matematika selama ini oleh peserta didik merupakan materi pembelajaran paling menyeramkan, sehingga banyak anak-anak kurang tertarik untuk mempelajarinya.Salah satunya yaitu materi tentang perkalian.Sedangkan Menurut Soesilowati (2016) "Perkalian adalah bentuk lain dari penjumlahan berulang. Untuk anak yang baru belajar perkalian, ada hal yang harus ditekankan bahwa yang sama adalah hasil perkaliannya saja. pengertian perkaliannya atau gambarnya tetap berbeda. Jadi, hasil perkalian dari $3 \times 1=1 \times 3=3$ tetapi pengertiannya adalah berbeda.Contoh konkretnya adalah soal minum obat pengertian perkalian $3 \times 1$ adalah obat itu diminum tiga kali sehari sebanyak satu butir setiap kali minum.Berbeda sekali pengertiannya dengan $1 \times 3$ yang artinya bahwa obat itu diminum satu kali sehari sebanyak tiga butir satu kali minum.Jadi, untuk memahami konsep perkalian anak harus paham dan trampil melakukan operasi penjumlahan". Menurut Smith \& Smith, (2009)) perkalian adalah operasi yang digunakan untuk menemukan produk ketika dua faktor di ketahui yaitu faktor $\mathrm{x}$ faktor $=$ produk. 
Perkalian adalah operasi matematika penskalaan satu bilangan dengan bilangan lain. Operasi ini adalah salah satu dari empat operasi dasar di dalam aritmatika dasar (yang lainnya adalah penjumlahan, pengurangan dan pembagian). Operasi perkalianmenurut (Djafar, 2018)adalah "penjumlahan berulangatau penambahan bilangan yang sama Contoh. Pada penjumlahan pada suku sama misalnya $5+5+5+5$ yang merupakan penjumlahan berulang serta dapat di sajikan dalam bentuk $4 \times 5$ dan disebut perkalian 4 dan 5".

Pengenalan konsep dasar matematika seharusnya sesuai dengan sifat unik anak, yaitu senang bermain(Aulina, 2018). Sehingga pendidik mampu mengintegrasikan karakteristik anak ke dalam pembelajaran yaitu menyediakan media pembelajaran yang dapat menarik perhatian anak dalam belajar.Menurut (Amar, Acevedo, \& Cordova, 2013)menyampaikan bahwa ada tiga tahap perkembangan mental anak, yaitu: 1) berfikir secara intuitif +4 tahun, 2) beroprasi secara kongkrit +7 tahun, 3) beroprasi secara formal + 11 tahun. Proses pembelajaran di lingkungan belajar siswa harus disesuaikan dengan tahap perkembangan siswa. Anak usia sekolah dasar umumnya berada pada tahap perkembangan mental beroprasi secara kongkrit. Oleh sebab itu pada pembelajarana di sekolah harus memberikan kondisi pembelajaran yang nyata.

Media pembelajaran dapat digunakan untuk menciptakan kondisi pembelajaran yang nyata.Dengan penggunaan media pembelajaran, pesan yang sifatnya abstrak dapat diubah menjadi pesan yang kongkrit. Kata media berasal dari bahasa latin yaitu medius yang berarti perantara atau pengantar. Menurut bahasa Arab kata media berarti perantara atau pengantar pesan dari pengirim kepada penerima pesan(Arsyad, 2011). Menurut Malapata \& Wijayanigsih (2019)media pembelajaran adalah segala sesuatu yang dapat menyalurkan pesan, dapat merangsang fikiran, perasaan, dan kemauan peserta didik sehingga dapat mendorong terciptanya proses belajar pada diri peserta didik. Sedangkan menurut Dariyati, Marhaeni, \& Widiartini (2019) media adalah semua bentuk perantara yang digunakan oleh individu dalam menyampaikan atau menyebarkan informasi, ide, atau gagasan agar dapat tersampaikan kepada penerima.

Berdasarkan observasi yang dilakukan peneliti terhadap beberapa sekolah dasar di kecamatan Kayutanam kabupaten Pariaman didapatkan hasil bahwapenggunaan media dalam pembelajaran di kelas 1 jarang menggunakan mediapembelajaran, kalaupun sudah menggunakanmedia pembelajaran hanya sebatasmenggunakan buku cetak dan LKA (LembarKerja Anak). Sehingga dalam pembelajaranmenjadi kurang optimal, anak cenderungkurang antusias dalam mengikutipembelajaran konsep perkalian anak usia dini. Oleh sebab itu peneliti ingin mengenalkan konsep perkalian pada anak usia 6-7 tahun dengan media rak telur rainbow.

Rak telur rainbow termasuk jenis media visual yang mudah ditemukan dan harganya murah serta diberi cat warna-warni yang dapat membuat siswa tertarik.Rak telur ini dibuat dari rak telur yang sudah tidak terpakai dan hendak di buang karena sudah menjadi sampah.Peneliti memanfaatkan sebagai alat peraga dalam pembelajaran.Rak telur itu di percantik dengan cat berwarna pelangi.Karena itu, peneliti menyebutnya rak telur rainbow.Media Rak Telur dan Kelereng peneliti gunakan untuk menanamkan konsep perkalian pada anak SD kelas 1 di beberapa SDN Kayutanam.

Media rak telur rainbow yang digunakan peneliti merupakan alat bantu yang digunakan guru saat menerangkan mata pelajaran matematika kepada anak SD kelas 1 yang dapat menambah pemahaman dan meningkatkan hasil belajar anak. Dengan adanya media rak telur rainbow ini diharapkan anak menjadi lebih tertarik untuk belajar dan tidak bosan saat pembelajaran berlangsung di dalam kelas.

Hasil penelitian Ridlo \& Riwanto (2018) menunjukkan bahwa Media Pembelajaran rak telur rainbow dapat digunakan dalam meningkatkan hasil belajar matematika anak. Penelitian ini relevan dengan penelitian yang akan penulis lakukan yaitu sama-sama membahas tentang media rak telur rainbow dengan metode kualitatif, tetapi bedanya pada penelitian yang penulis lakukan lebih terfokus kepada konsep pengenalan perkalian pada 
anak.Penelitian yang dilakukan oleh Hartini(2019) menjelaskan bahwa dengan media rak telur dapat meningkatkan hasil belajar matematika anak usia dini, dengan metode course review horay. Sedangkan hasil penelitian peneliti ini tidak menggunakan metode tersebut.

Beberapa penelitian menunjukkan bahwa dengan media rak telur rainbow yang digunakan dapat menjadi media perangsang untuk anak dalam pengenalan konsep perkalian. Sehingga peneliti tertarik menggunakan media tersebut dengan tujuan penelitianini agar anak mengetahui dasar-dasar pembelajaran berhitung/matematika terkhusus perkalian awal, sehingga pada saat nanti anak akan lebih siap mengikuti pembelajaran matematika pada jenjang pendidikan selanjutnya yang lebih komplek. Selain itu guru juga dapat lebih berkreasi dan terinovasi dalam memanfaatkan bahan-bahan yang ada untuk proses pembelajaran anak didik di sekolah.

\section{METODOLOGI}

Metode yang digunakan dalam penelitian ini adalah diskriptif kualitatif. Subjek penelitian ini adalah anak SD kelas 1 dengan jumlah 25 anak.Teknik pengumpulan data yang digunakan adalah demonstrasi, Kelompok dan Dokumentasi.Alat pengumpulan data yang digunakan berbentuk catatan lapangan, dan dan kamera.Analisis data menggunakan langkah-langkah yang dikemukakan oleh Miles dan Huberman dalam (Suryana, 2016) yaitu pengumpulan data (data collection), reduksi data (data reduction), display data (data display), verifikasi dan penegasan kesimpulan (conclution drawing and verivication).

\section{HASIL DAN PEMBAHASAN}

Matematika selama ini oleh peserta didik merupakan materi pembelajaran paling menyeramkan, sehingga banyak anak-anak kurang tertarik untuk mempelajarinya. Salah satunya yaitu materi tentang perkalian.Anak usia 6-7 tahun umumnya berada pada tahap perkembangan mental beroprasi secara kongkrit. Oleh sebab itu pada pembelajaran disekolah guru harus memberikan kondisi pembelajaran yang nyata.Menurut Djafar (2018)Operasi perkalian adalah penjumlahan berulang atau penambahan bilangan yang sama.

\section{Tahap Demonstrasi}

Langkah-langkah pengenalan konsep perkalian melalui media rak telur rainbow dalam pembelajaran matematika pada tahap demonstrasi: (1) Guru menjelaskan jumlah lubang yang ada pada rak telur yang di pegang dan jumlah kelereng yang akan dimasukan kedalam rak telur tersebut. (2) Guru mendemonstrasikan didepan kelas dengan mengisi lubang pada rak tersebut dengan kelereng, sementara itu anak lain memperhatikannya.

(3) Anak melihat guru mempraktekan penggunaan media rak telur rainbow maka guru menyuruh anak maju kedepan kelas untuk mendemonstrasikan media rak telur rainbow tersebut sesuai dengan instruksi yang di berikan, sementara anak lain memperhatikannya secara bersama-sama, dengan contoh soal yang diberikan yaitu perkalian $3 \times 4$. Maka siswa tersebut diminta mengambil kelereng dan mengisi 4 lubang pada rak telur masing- masing 3 buah setiap lubangnya. Kemudian guru menyuruh anak tersebut berhitung bersama-sama jumlah semua kelereng yang ada di setiap lubang dengan mengajak anaklain menghitung bersama-sama.

$$
\begin{gathered}
3+3+3+3=12 \\
\text { Jadi } 3 \times 4=12
\end{gathered}
$$

(4) Guru memberikan apresiasi kepada anak yang tampil dengan mengajak semua anak bertepuk tangan. Setelah itu semua anakakan berebutan untuk memperagakannya 


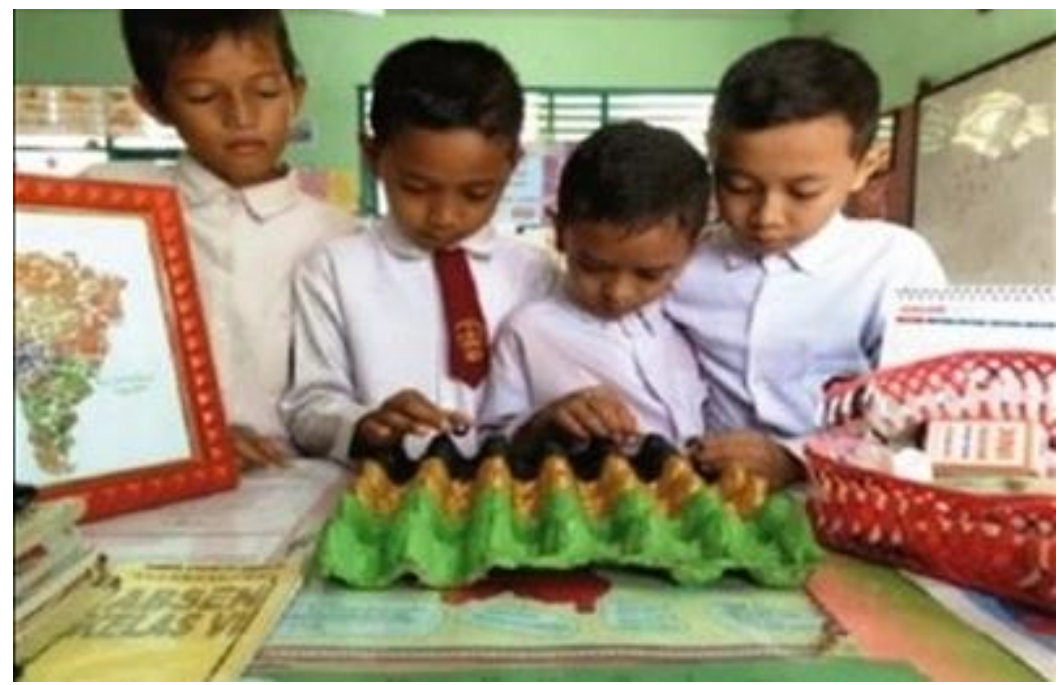

Gambar 1. Proses anak mempraktekkan media rak telur rainbow

Tabel 1. Penilaian guru terhadap anak dengan Teknik Demonstrasi

\begin{tabular}{lcccccc}
\hline \multicolumn{1}{c}{ Indikator yang dinilai } & \multicolumn{3}{c}{ Jumlah anak yang mendapat nilai terbaik } \\
& $\begin{array}{c}\text { Kurang } \\
\text { baik }\end{array}$ & Cukup & Baik & Sangat Baik \\
\hline $\begin{array}{l}\text { Anak mampu mengambil } \\
\text { kelereng dan mengisi 4 lubang } \\
\text { pada rak telur masing- masing }\end{array}$ & - & - & 10 anak yang & 15 anak yang \\
3 buah setiap lubangnya & & & dapatpenilaian & mendapat kan \\
baik dari guru & sangat baik dari \\
guru
\end{tabular}

Dari tabel di atas dapat dilihat bahwa hasil penilaian guru terhadap anak dengan menggunakan media rak telur rainbow mendapatkan penilaian yang memuaskan, sehingga guru lebih termotivasi dalam membuat media yang menarik lainnya, dan menjadi salah satu solusi bagi guru dalam mengenalkan konsep perkalian pada anak SD kelas 1.

\section{Tahap Kelompok/Kerjasama}

Pada tahap kedua guru membagi anak didik perkelompok dengan memberikan media rak telur rainbow pada masing-masing kelompok.Supaya semua anak dapat mencoba dan mempraktekan sendiri. Menurut (Buijzen \& Valkenburg, 2007)kerja sama penting untuk diajarkan sejak dini karena kemampuan kerja sama sangat dibutuhkan dalam kehidupan bermasyarakat. Sedangkan(Suyanto, 2005) mengklasifikasikan empat elemen dasar dalam kerja sama, yaitu: (1) adanya saling ketergantungan yang saling menguntungkan pada anak dalam melakukan usaha secara bersamasama, (2) adanya interaksi langsung diantara anak dalam satu kelompok, (3) masing-masing anak memiliki tanggung jawab untuk bisa menguasai materi yang diajarkan, (4) penggunaan kemampuan interpersonal dan kelompok kecil secara tepat, yang dimiliki oleh setiap anak.

Untuk melihat apakah anak mengerti dengan pengenalan konsep perkalian yang telah diajarkan, maka guru memberikan contoh soal perkalian dan menuliskannya di papan tulis.Lalu anak tersebut disuruh menjawab soal tersebut dengan mempraktekkan media rak telur rainbow bersama-sama dengan teman sekelompoknya.Disini anak tampak antusias dalam mengerjakan latihan yang diberikan guru dengan menggunakan media yang disiapkan guru. 


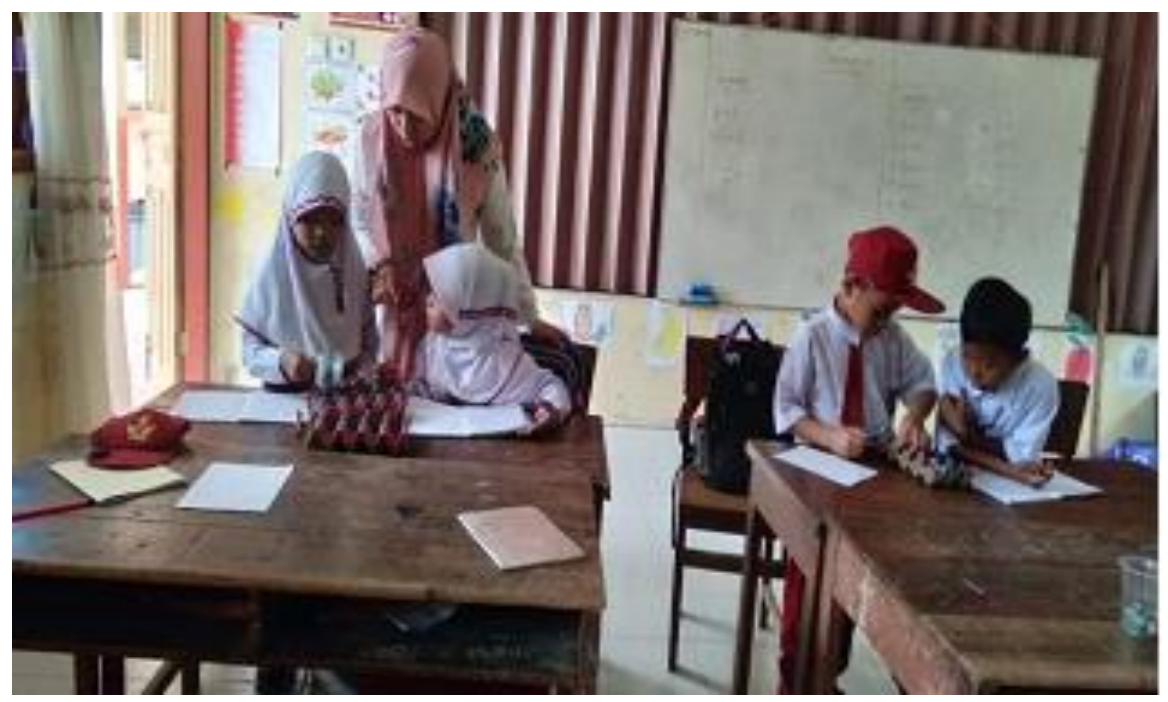

Gambar 2. Proses anak mempraktekkan media rak telur rainbow

Tabel 2. Penilaian guru terhadap anak dengan teknik Kelompok

\begin{tabular}{|c|c|c|c|c|}
\hline \multirow[t]{2}{*}{ Indikator Yang Di Nilai } & \multicolumn{4}{|c|}{ Penilaian yang diperoleh anak } \\
\hline & $\begin{array}{c}\text { Kelompok } \\
1\end{array}$ & $\begin{array}{c}\text { Kelompok } \\
2\end{array}$ & $\begin{array}{c}\text { Kelompok } \\
3\end{array}$ & $\underset{4}{\text { Kelompok }}$ \\
\hline $\begin{array}{l}\text { Anak dapat menjawab perkalian } \\
\text { dengan menggunakan rak telur } \\
\text { rainbow, dengan soal : } 3 \times 4 \text { dengan } \\
\text { cepat }=\ldots . . . \ldots . . . . . . . \text {, (dengan catatan } \\
\text { yang tercepat) }\end{array}$ & Baik & Baik & Sangat baik & $\begin{array}{c}\text { Sangat } \\
\text { Baik }\end{array}$ \\
\hline
\end{tabular}

Dari tabel di atas dapat dilihat bahwa hasil penilaian guru terhadap anak dengan membagi anak dalam 4 kelompok menggunakan media rak telur rainbow mendapatkan penilaian yang memuaskan.Sehingga waktu dalam memberi pelajaran konsep perkalian pada anak lebih efektif dari pada tidak menggunakan media ataupun menggunakan media yang tidak menarik.

\section{Pembahasan}

Pembelajaran perkalian pada anak usia dini merupakan operasi dasar matematika yang harus diajarkan dengan baik oleh guru, yang merupakan modal awal untuk mempelajari materi-materi lain dalam matematika. Begitu pentingnya guru harus mampu memanfaatkan media yang ada untuk mengajarkan kepada anak mengenai konsep perkalian. Media rak telur rainbow merupakan salah satu media yang efektif digunakan guru dalam pelaksanaan pembelajaran konsep berhitung di SD kelas 1 di beberapa SDN Kayutanam.

Proses yang dilakukan guru dalam pembelajaran perkalian dengan menggunakan media rak telur rainbow pada anak dilakukan dengan beberapa tahap, yaitu: (1) guru memperlihatkan dan menjelaskan media rak telur rainbow pada anak; (2) guru membimbing anak dalam menggunakan media rak telur rainbow secara individu maupun berkelompok; (3) guru mengamati anak dalam menggunakan media rak telur rainbow; (4) guru menilai kemampuan anak dengan menggunakan media rak telur rainbow.

Berdasarkan dari pelaksanaan pembelajaran yang dilaksanakan dengan teknik demonstrasi dapat dilihat bahwa anak sangat antusias dan sangat semangat, ini terbukti ketika guru meminta anak maju kedepan, anak berlomba ingin maju untuk mempraktikkan yang di instruksikan guru, dan anak mampu mengambil kelereng dan mengisi 4 lubang pada rak telur masing- masing 3 buah setiap lubangnya. (Huda, 2017)mengatakan tahap demonstrasi merupakan pembelajaran yang efektif, karena peserta didik dapat mengetahui 
secara langsung penerapan materi tersebut dalam kehidupan sehari-hari.Hasil penilaian guru terhadap anak dengan menggunakan media rak telur rainbow mendapatkan penilaian yang memuaskan terbukti 15 anak yang mendapat kan penilaian sangat baik dan 10 anak mendapatkan penilaian baik, tidak ada anak mendapatkan penilaian kurang baik atau cukup baik.

Sedangkan teknik berkelompok anak dapat menjawab perkalian dengan cepat terbukti anak mampu menjawab soal yang diberikan guru yaitu $3 \times 4$ dengan menggunakan media rak telur rainbow. (Sanusi, 2016) mengatakan dengan teknik berkelompok membantu anak dalam memecahkan masalah dan juga membuktikan pribadi yang baik terhadap kerja sama anak. Hasil penilaian guru terhadap anak dengan membagi anak dalam 4 kelompok menggunakan media rak telur rainbow mendapatkan penilaian yang memuaskan. Hasil penilaian guru terhadap anak dengan membagi anak dalam 4 kelompok menggunakan media rak telur rainbow mendapatkan penilaian yang memuaskan terbukti 2 kelompok yang mendapatkan nilai baik dan 2 kelompok yang mendapatkan nilai sangat baik, tidak anak anak yang mendapatkan nilai cukup atau kurang.

Dari penelitian yang telah dilakukan nampak jelas bahwa penggunaan rak telur rainbow dalam proses pembelajaran dapat dikatakan sebagai media belajar karna mampu memberi rangsangan kepada anak didik untuk merasa senang dalam proses pembelajaran. Dengan demikian, penggunaan media rak telur rainbow dalam proses belajar mengajar akan membantu anak dalam memahami konsep perkalian. Hal ini sesuai dengan pendapat Dariyati, Marhaeni, \& Widiartini (2019) media rak telur rainbow dapat membantu anak fokus dalam pembelajaran karena benda yang dihitung dapat dipegang dan menjadi anak paham terhadap konsep perkalian. Sesuai dengan pendapat Ridlo \& Riwanto (2018) mengatakan bahwa dengan media rak telur rainbow dapat menarik perhatian anak untuk belajar karena medianya yang berwarna dan mengasyikkan.

Menurut Hartini(2019) juga berpendapat bahwa media rak telur rainbow efektif digunakan untuk pembelajaran konsep perkalian pada anak. Untuk itu dengan disajikan konsep abstrak matematika dalam bentuk konkrit, maka anak pada tingkat-tingkat lebih rendah akan lebih meahami. Anak akan lebih menyadari adanya hubungan pembelajaran dengan yang ada disekitarnya. Selain itu dengan rak telur rainbow ini sebagai upaya guru untuk mengefektifkan komunikasi dan interaksi guru dan anak dalam proses pembelajaran konsep perkalian.

Dapat dipahami bahwa penggunaan media rainbow dengan teknik demonstrasi dan teknik kelompok pada anak usia 6-7 tahun di SD sangat efektif sebagai media pembelajaran perkalian awal. Hal ini membuktikan bahwa media rak telur rainbow diterapkan pada pelaksanaan pembelajaran perkalian awal pada anak usia dini dengan teknik demonstrasi dan teknik kelompok akan memudahkan anak dalam belajar perkalian dan memudahkan guru dalam mengajar perkalian.

\section{SIMPULAN}

Pengenalan konsep perkalian menggunakan rak telur rainbow membuat anak tidak takut lagi belajar matematika dan pembelajaran matematika jadi menyenangkan.Sehingga tujuan pembelajaran dapat tercapai.Penggunaan media rak telurrainbow selain menyenangkan, disini kita juga bisa melihat kerjasama anak dalam berkelompok, dan perkembangan kognitif anak menjadi berkembang karena media rak telur rainbow ini memberikan bentuk konkrit dari konsep perkalian, yang salah satu konsepnya yaitu penjumlahan yang berulang.

\section{UCAPAN TERIMAKASIH}

Terima kasih terutama kepada orang tua atas doa dan dukungannya dan terimakasih kepada dosen pembimbing dan teman-teman untuk menyemangatinya dan 
DOI: $10.31004 /$ obsesi.v4i2.370

juga Jurnal Obsesi : Jurnal Pendidikan Anak Usia Dini yang telah memberikan masukan dalam penulisan artikel ini.

\section{DAFTAR PUSTAKA}

Abin, samsudin makmun. (2017). PsikologiPendidikan. Bandung: PT RosdaKaryaRemaja.

Amar, D., Acevedo, G. A., \& Cordova, A. (2013). Affordances In The Home Environment For Motor Development: A Cross-Cultural Study Between American and Lebanese Children. Hindawi Publishing Corporation, 3(1), 5. https://doi.org/10.31004/2013/152094

Ani, A., Maulana, M., \& Sunaengsih, C. (2018). Pentingnya media pembelajaran terhadap perkembangan anak usia dini. Jurnal Pena Ilmiah, 2(1), 971-980.

Arsyad, A. (2011). Media Pembelajaran. Jakarta: Rajawali pers Depdiknas. 2003. Pedoman penulisan modul. Direktorat Pendidikan Menengah Kejuruan. Jakarta ....

Astuti, R., \& Aziz, T. (2019). Integrasi Pengembangan Kreativitas Anak Usia Dini di TK Kanisius Sorowajan Yogyakarta. Jurnal Obsesi : Jurnal Pendidikan Anak Usia Dini, 3(2), 294. https:// doi.org/10.31004/obsesi.v3i2.99

Aulina, C. N. (2018). Penerapan Metode Whole Brain Teaching dalam Meningkatkan Motivasi Belajar Anak Usia Dini. Jurnal Obsesi : Jurnal Pendidikan Anak Usia Dini, 2(1), 1. https:// doi.org/10.31004/obsesi.v2i1.1

Buijzen, M., \& Valkenburg, P. M. (2007). Developing a Typology of Humor in Audiovisual Media. Journal of Advertising, 6(2). https://doi.org/https://doi.org/10.1207/s1532785xmep0602_2

Dariyati, G. A., Marhaeni, A. A. I. ., \& Widiartini, N. K. (2019). Pengaruh Pembelajaran Praktik Berbantuan Media Audio Terhadap Kemampuan Motorik dan Motivasi Belajar Anak Usia Dini. Jurnal Obsesi: Jurnal Pendidikan Anak Usia Dini, 3(1), 233. https://doi.org/10.31004/obsesi.v3i1.181

Djafar. (2018). Pembelajaran matematika sekolah dasar. Bandung: Yayasan Nuansa Cendia.

Fauziddin, M., \& Mufarizuddin, M. (2018). Useful of Clap Hand Games for Optimalize Cogtivite Aspects in Early Childhood Education. Jurnal Obsesi : Jurnal Pendidikan Anak Usia Dini, 2(2), 162. https:// doi.org/10.31004/obsesi.v2i2.76

Hartini, H. (2019). Penerapan Model Problem Based Learning dengan Media Rak Telur Rainbow untuk Meningkatkan Hasil Belajar Matematika pada Siswa Kelas II SDN Ajung 02 Jember (Semester II Tahun Pelajaran 2017-2018). ELSE (Elementary School Education Journal): Jurnal Pendidikan Dan Pembelajaran Sekolah Dasar, 3(1).

Huda, M. (2017). Model-Model Pengajaran dan Pembelajaran. Yogyakarta: Pustaka Belajar.

Malapata, E., \& Wijayanigsih, L. (2019). Meningkatkan Kemampuan Berhitung Anak Usia 45 Tahun melalui Media Lumbung Hitung. Jurnal Obsesi : Jurnal Pendidikan Anak Usia Dini, 3(1), 283. https:// doi.org/10.31004/obsesi.v3i1.183

Ridlo, L., \& Riwanto, M. A. (2018). Penggunaan Media Rak Telur Rainbow dalam Meningkatkan Hasil Belajar Matematika Materi Perkalian dan Pembagian Kelas II SD Negeri Karangasem 011 Fadilah Wahyu Suyuti, 2.

Smith, S. S., \& Smith, S. S. (2009). Early childhood Motoric. 2(2).

Soesilowati. (2016). Konsep matematika sekolah dasar. Jakarta selatan: Referensi.

Suryana, D. (2016). Pendidikan Anak Usia Dini: Stimulasi \& Aspek Perkembangan Anak. Jakarta: Prenada Media.

Suryana, D., Elina, E., Nurevi, N., \& Ratnawilis, R. (2015). Model Pembelajaran Berbasis Pendekatan Saintifik pada Taman Kanak-kanak di Kota Padang.

Suyanto, S. (2005). Konsep dasar pendidikan anak usia dini.

Yaswinda, Y., Yulsyofriend, Y., \& Mayar, F. (2018). Pengembangan Bahan Pembelajaran Sains Berbasis Multisensori Ekologi Bagi Guru Paud Kecamatan Tilatang Kamang Kabupaten Agam. Yaa Bunayya: Jurnal Pendidikan Anak Usia Dini, 2(2), 13-22. 